\title{
INDONESIAN RURAL EFL TEACHER'S STRATEGY IN TEACHING HIGHER ORDER THINKING SKILLS
}

\author{
Novita Silta Pasutri \\ Universitas Islam Negeri Sultan Syarif Kasim Riau, Indonesia \\ Email: novita.silta281@yahoo.com \\ Bukhori \\ Universitas Islam Negeri Sultan Syarif Kasim Riau, Indonesia \\ Email: bukhori.elmeskumy@gmail.com \\ Helmiati \\ Universitas Islam Negeri Sultan Syarif Kasim Riau, Indonesia \\ Email: emikahar@yahoo.com
}

\begin{abstract}
This research aims to explore the rural teacher's strategy in teaching Higher Order Thinking Skills based on the 2013 curriculum. By using qualitative approach, the researchers collect the data employs nonparticipant observation in the teaching and learning process, interviewed the English teacher, also documents by collecting the lesson plan made by one of the English teacher in one of Junior High School in Gaung District. The result of this research showed that the teacher used determining learning objectives with the eight characteristics of the lesson plan for 2013 curriculum, teach through questioning with LOTS questions, practice before assessment but it's not effective, also provide assessment and feedback to develop students' Higher Order Thinking Skills. The researchers also found that the teacher miss the step of review, refine and improve because she did not collect the students' feedback. Based on the finding above, the researchers conclude that the teacher has been trying to do the steps to develop the students' HOTS, but the development of HOTS in the rural area is not reach the expectation of the Higher Order Thinking based on 2013 curriculum.
\end{abstract}

Keywords: strategy, Higher Order Thinking Skills (HOTS), rural area

\begin{abstract}
Abstrak
Penelitian ini bertujuan untuk meneliti strategi guru di pedesaan dalam mengajarkan kemampuan berpikir tingkat tinggi berdasarkan Kurikulum 2013. Dengan menggunakan pendekatan kualitatif, peneliti mengumpulkan data melalui pengamatan dengan tidak terlibat sebagai peserta dalam proses belajar mengajar, melakukan wawancara pada guru bahasa Inggris, serta menggunakan dokumen dengan mengumpulkan rencana pelaksanaan pembelajaran yang dibuat oleh salah satu guru bahasa Inggris pada salah satu sekolah di Kecamatan Gaung. Hasil dari penelitian ini menunjukkan bahwa guru menentukan tujuan pembelajaran dengan delapan karakteristik rencana pelaksanaan pembelajaran pada Kurikulum 2013, mengajar melalui pertanyaan
\end{abstract}


dengan pertanyaan jenis LOTS, latihan sebelum penilaian namun belum efektif, serta memberikan penilaian dan umpan balik untuk mengembangkan kemampuan berpikir tingkat tinggi siswa. Peneliti juga menemukan bahwa guru mengabaikan langkah memeriksa, menyaring, dan meningkatkan karena beliau tidak mengumpulkan umpan balik dari siswa. Berdasarkan hasil penelitian tersebut, peneliti menyimpulkan bahwa guru sudah mencoba untuk mengikuti langkah-langkah dalam mengembangkan kemampuan berpikir tingkat tinggi siswa, namun pengembangan kemampuan berpikir tingkat tinggi di daerah pedesaan belum memenuhi harapan dari kemampuan berpikir tingkat tinggi berdasarkan Kurikulum 2013.

Kata Kunci: strategi, Kemampuan Berpikir Tingkat Tinggi, daerah pedesaan

\section{A. Introduction}

Bloom's taxonomy is a model thinking developed by Benjamin S. Bloom in 1956. This model divided thinking skills into six cognitive levels. Then, in the 1990s Lorin Anderson, a former student of Bloom's create a draft to update Bloom's taxonomy.

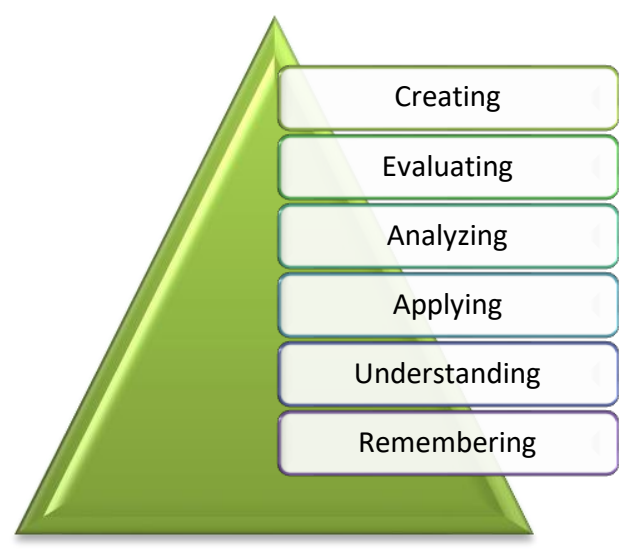

Figure 1 The level of thinking ${ }^{1}$

The change of the cognitive levels in Bloom's taxonomy are:

Those cognitive levels divided into three levels of thinking, the Lower Order Thinking Skill (remembering), Middle Order Thinking Skills (understanding and

${ }^{1}$ Mary Forehand, "Bloom's Taxonomy, Emerging Perspectives on Learning, Teaching and Technology,” 2011, http://projects.coe.edu/epltt/index.php 
applying), and Higher Order Thinking Skills (analyzing, evaluating, and understanding). ${ }^{2}$ The keywords of the cognitive levels are: ${ }^{3}$

1. Remembering means the students can mention the definition, imitate the pronunciation, state the structure, pronounce, and repeat.

2. Understanding means the students can explain the concept, principle, law or procedure. The keywords are classified, describe, explain the identification, place, report, explain, translate, and paraphrased.

3. Applying means the students can apply their understanding in a new situation. The keywords are choosing, demonstrating, acting, using, illustrating, interpreting, arranging schedule, making sketch, solving problem and writing.

4. Analyzing means the students can classify the sections based on their difference and similarity. The keywords are examining, comparing, contrasting, distinguish, doing discrimination, separating, test, doing an experiment, and asking.

5. Evaluating means the students can state either good or bad towards a phenomenon or certain object. The keywords are giving argumentation, defining, stating, choosing, giving support, giving assessment, and doing evaluation.

6. Creating means the students can create a thing or opinion. The keywords for creating are assembling, change, build, create, design, establish, formulate, and write.

High order thinking is active when someone faces unfamiliar problems, uncertainties, questions or dilemmas. Thinking as HOTS try to solve the problems by multiple solutions (creative problem-solving), considerable mental energy directed toward problem solving, subtle less than obvious decision about strategy, transferable some criteria to the problem-solving process, problems that do not provide a clear starting point, some degree metacognition and self-awareness, development and application of new theories onto sets of facts and problems. ${ }^{4}$ In short, HOTS lead to handling situations that we have not encountered before.

\footnotetext{
${ }^{2}$ David R. Krathwohl, “A Revision of Bloom's Taxonomy, An Overview,” Theory into Practice, Vol. 41, No. 4 (2002): 212 - 264

${ }^{3}$ Mary Forehand, "Bloom's Taxonomy..."

${ }^{4}$ Bhawani Prasad Mainali, "Higher Order Thinking in Education," Academic Voices, Vol. 2, No. 1 (2012): 5-10
} 
There are two types of HOTS needed for problem-solving; analytical (logical) and creative. Analytical or logical skills consist of ordering, comparing, contrasting, evaluating and selecting. It uses critical thinking skills to select the best alternative or answer about the problems. On the other hand, creative thinking is useful to the same reason as analytical and logical thinking. It consists of problem finding, efficiency, flexibility, originality, and elaboration. ${ }^{5}$

The culture such as the students itself, the teachers, and also parents must give support to the development of higher-order thinking. The opportunity to show high thinking to solve the problem needed to see and develop their ability to think. If the student gets that opportunity, they can solve the problem in creative ways. There are some steps to develop students high order thinking. ${ }^{67}$ It can be seen in the figure 2 below.



Figure 2. The process to develop Higher Order Thinking Skills

There are five steps to teaching the students' Higher Order Thinking Skills. The first step is determining learning objectives. This step focus on how the teacher design the lesson plan. The principle of the lesson plan based on the 2013 curriculum are giving attention to the characteristics of the students, focus on the students' participation, student center, develop the students' interest to read and write, giving feedback to the students, emphasize the interrelationship between basic competencies, learning material, learning activities, indicators of competency achievement, assessment

\footnotetext{
${ }^{5}$ Jamal Raiyn, "The Role of Visual Learning in Improving Students' Higher-Order Thinking Skills," Journal of Education and Practice, Vol. 07, No. 24 (2016): 115-121

${ }^{6}$ Barbara Limbach \& Wendy Waugh, "Developing Higher Order Thinking," Journal of Instructional Pedagogies, Vol. 3 (2010): 1-9

${ }^{7}$ Merta Dhewa Kusuma, Undang Rosidin, Abdurrahman, and Agus Suyatna, "The Development of Higher Order Thinking Skills (HOTS) Instrument Assessment in Physics Study," Journal of Research and Method in Education, Vol. 7, No. 1 (2017): 26-32
} 
and sources, integrated thematical learning, and use technology in the process of teaching and learning. ${ }^{8}$

The second step of the teaching HOTS is teach through questioning. Questioning can give the greatest impact in developing students' HOTS. ${ }^{9}$ Then, the teacher should give practice before assessment. After that, the teacher should review, refine and improve the learning materials by collecting feedback from the students. The final step in the process of the teaching students' HOTS is provide assessment and feedback. Teaching about thinking skills requires the teacher to understand the ability to think itself. There is a gap between teachers' knowledge and their actual practice in teaching skillful thinking. He found that the teachers lacked knowledge on skillful thinking and they were unable to implement and infuse the elements of skillful thinking. ${ }^{10}$

Many policymakers set the standard of rural area, but it is still not fix as the definition of the rural area itself. Defining rural can be based on stereotype and personal experiences. The definition of rural area is the term suggests pastoral landscapes, unique demographic structures and settlement patterns, isolate place, have a low population, extractive economic activities, and distinct socio-cultural milieus. ${ }^{11}$ Then other experts define that rural communities live in a small size area, sparse settlement, distance from population concentrations, and economic reliance on agricultural industries that are increasingly using seasonal and immigrant workers to minimize labor costs. ${ }^{12}$

However, in Indonesia, the definition of rural areas has been stipulated in Law Number 7 of 1983 concerning Income Tax as amended by Law Number 7 of $1991 .{ }^{13}$ In this Law, it is stated that rural areas are areas that have economic potential in the form of sources. natural resources in agriculture, forestry, mining, tourism, and industry, but the state of available economic infrastructure and facilities is still limited so that to convert the available economic potential into real economic strength, investors need to

\footnotetext{
${ }^{8}$ Helmawati, Pembelajaran and Penilaian Berbasis HOTS, Higher Order Thinking Skills (Bandung: PT Remaja Rosdakarya, 2019), 169

9 Barbara Limbach \& Wendy Waugh, "Developing Higher...," 1-9

${ }^{10}$ Bavani Nageswana Row, Selvaranee Subramaniam, Renuka V. Sathasivam, "When Students Say 'I Just Couldn't Think': Challenges in Teaching Skilful Thinking," The Malaysian Online Journal of Educational Sciences, Vol. 4, No. 2 (2016): 59-69

${ }^{11}$ L. Gary Hart, Eric H. Larson, and Denise M. Lishner, "Rural Definition for Health Policy and Research," American Journal of Public Health, Vol. 95, No. 7 (2005): 1149-1155.

${ }^{12}$ Marleen Schouten, C. Martijn van der Heide, Wim J.M. Heijman," Resilience of SocialEcological Systems in European Rural Areas: Theory and Prospects," Research Gate, January 2009, Available at https://www.researchgate.net/publication/46472588

${ }^{13}$ Law Number 7 of 1991
} 
build at their own expense the infrastructure and facilities they need, such as roads, ports, electricity, telecommunications, water, employee housing, health services, schools, places of worship, markets and other social needs, which require large costs. This is the basis for the researcher to say that Teluk Kabung Village, Gaung District, Indragiri Hilir, Riau is one of the areas classified as a rural area.

This research was conducted in a Junior High School in Teluk Kabung, Gaung District, Indragiri Hilir, Riau. Even though this school located in a village, the school still has to live up the provisions and targets set out in the 2013 Curriculum, where they must develop the students' higher-order thinking skills. However, the result of the preobservation that the researcher did in this school showed that the students' thinking ability is in the low and middle level. The students are more silent and listen to the teacher's explanation rather than asking questions or giving their opinion during the lesson.

The previous research related to the Higher Order Thinking Skills such as from Sangmin-Michelle Lee ${ }^{14}$ who analyze the collage students in Korea about the correlation between cognitive presence, the value of social presence, and the relationship between them to the Higher Order Thinking Skills. He found that high cognitive presence density did not guarantee the Higher Order Thinking Skills, but the social presence is positively related to the cognitive presence. On 2015 Yen and Halili found that the teacher have to realize that the effectiveness of teaching HOTS only when the students active in the process of teaching and learning. Baki, Galea, and Nimchcisalem ${ }^{15}$ also did the research to find the level of rural students' critical thinking in Malaysia, and found that rural students are not familiar with the critical thinking.

All of those research stated there are still problems to teaching Higher Order Thinking Skills. The research that focus on the student' skill only held in Malaysia and the research from Retnawati Djiu, Kartianom, Apino, and Anazifa ${ }^{16}$ found that teachers' knowledge and their ability to improve students' HOTS is still low. Practically, based

\footnotetext{
${ }^{14}$ Sangmin-Michael Lee, "The Relationship Between Higher Order Thinking Skills, Cognitive Density, and Social Presence In Online Learning," Internet and Higher Education, 21 (2014): 41 - 52

${ }^{15}$ Nurshila Umar Baki, Shammemm Rafik-Galea, and Vahid Nimehchisalem, "Malaysian Rural ESL Students Critical Thinking Literacy Level: A Case Study," International Journal of Education and Literacy Studies, Vol. 04, No. 04 (2016): 71-80

${ }^{16}$ Heri Retnawati, Hasan Djiu, Kartianom, Ezi Apino, and Rizqa D. Anazifa, "Teachers' Knowledge About Higher-Order Thinking Skills and Its Learning Strategy," Problem of Education in the $21^{\text {st }}$ Century, Vol. 76, No. 2 (2018): 215-230
} 
on the observation that the researchers did in the rural area, the researchers found that students in the rural area ais passive in the teaching and learning process, limited school facility to support the teachers to teach, and the students have lack English proficiency. This is a gap of this research, since the teachers' knowledge and their ability on developing HOTS is still low, and there are some challenges in teaching in the rural area, how can the teacher develop the students' HOTS especially in a rural area in Indonesia. So, this resarch investigated the rural EFL teacher's strategy to in teaching Higher Order Thinking Skills.

\section{B. Method}

The researchers used the qualitative approach which has the characteristic of natural (natural setting) and source the data directly. The researchers use the case study approach to explain about the rural EFL teacher's strategy in teaching higher order thinking skills. This research taken in one of the villages in Gaung district, it calls Teluk Kabung. The participant of the research was chosen only one English teacher in a junior high school who work in a small village in Gaung district. The researchers collected the data from the non-participant observation, one on one or individual interview, and collected the lesson plan made by the English teacher. This data analyzed with the steps of transcribing, coding, categorizing, interpreting, and validating the finding by using the triangulation based on the types of data.

\section{Finding and Discussion}

Based on the observation, interview, and the data from the documents, the researchers indicate that the teacher plays the important part to develop their students' Higher Order Thinking Skills. The teacher applied the steps to develop students' high order thinking as Limbach and Waugh ${ }^{17}$ and Kusuma, Rosidin, Abdurrahman, and Suyatna ${ }^{18}$ state in their research. The teacher did the determining learning objectives, teach by questioning, practice before assessment, and provide assessment and feedback. The teacher miss the step of review, refine, and improve in teaching and learning process. Even the teacher has been applied the steps to develop the Higher Order

\footnotetext{
${ }^{17}$ Barbara Limbach \& Wendy Waugh, "Developing Higher..., 1- 9

${ }^{18}$ Merta Dhewa Kusuma, Undang Rosidin, Abdurrahman, and Agus Suyatna, "The Development of Higher..., 26-32
} 
Thinking Skills (HOTS) the junior high school students in rural area still cannot reach the expectation to think as HOTS.

\section{Teaching HOTS in Determining Learning Objective}

Based on the documents from the lesson plan made by the teacher, the researchers found that the teacher did the steps of determining learning objective. This finding also in line with the teacher's statements in the interview that explained the way she design the lesson plan to develop the rural students' Higher Order Thinking Skills. The points of the lesson plan to develop students high thinking skills are:

\section{a. The Students' Characteristics}

The researchers found that the teacher create the lesson plan considering to the students' characteristics, especially for the students' environment. She wrote in her lesson plan:

\footnotetext{
"The ongoing activities and the events in the students' house, school and their environment that can influencing the students' behavior such as the target of basic competence."
}

The standard competence that the teacher choose in her lesson plan can help the students to think about the real events in their life. Since the standard competence is about the students' daily activity, it can stimulate the students' Higher Order Thinking Skills (HOTS). Teacher's attention to the students' characteristic can also found in interview. The teacher explained that her students has different characteristics, and she divide the students into some groups based on their characteristics. However, not all the teaching strategy can be used in this school. The teacher stated that the teaching strategy that can be use only the discussion, speech, and role-play. The reason to use this strategy is that of the situation in the school did not support to use another strategy. It means that the teachers wrote the lesson plan and choose strategy is based on the students' characteristics in a rural school.

The finding about the students' characteristics in the lesson plan related to the Helmawati's theory about the principle of the lesson plan in 2013 curriculum that the teacher should give attention to the students' characteristics such as knowledge, intellectual level, talents, potential, interest, learning motivation, social abilities, emotions, learning styles of special needs, learning speed, background, culture, norms, values, and environment. However, in this research, the teacher give her attention to the students' basic knowledge, intellectual level, and learning styles of special needs. So, 
the teacher use the strategy of discussion, speech and role-play to develop the students' Higher Order Thinking Skills in English class.

\section{b. The Students' Participation}

The method of teaching and learning set by the teacher focus on the students' participation because the teacher arrange the teaching method for the fist meeting and the second meetings was project based learning, then question and answer, group discussion, and role-play for the third meeting, and question and answer with group discussion method for the fourth and fifth meetings. All of those methods can provoke the students to participate in the teaching and learning process. The researchers also noted some statements from the teacher in the interview process that indicate that the teacher set the plan to make the students participate in the teaching and learning process. The teacher said:

"The way to do that is like I've been explain just now. Ooo the student A is a passive student. So, to make her active in the classroom, I will make her in the same group with the active student."

In this part, the teacher explain her plan to make the students participate in the English class. According to the teacher, the best way to make all students participate in the teaching and learning process is to make the passive students join to the active students.

\section{c. Student Center}

As the data that the researchers collected from the lesson plan and interview with the teacher, the researchers found that the teacher design her lesson plan with the student center class. To prove that the teacher design a student center lesson plan, the researchers use the whilst-activities in the lesson plan.

The teacher divide activity in the lesson plan into three parts. The first part is sharing information, in this part the teacher let the students to observe and asking questions related to the teaching materials. Then, the teacher divide the students into some groups and work in the group. The teacher ask the students to collect the information about the learning materials and discuss to their groups. After the students collect and discuss the information about the learning materials, the teacher ask the students to communicate their finding to other groups.

This plan shows that the teacher tried to create a student center class where most of the activities focused to the students. In this case, the teacher used scientific approach 
in English lesson plan. This approach is one of the student center approach because almost all the process of teaching and learning activity can make the student be more active than the teacher itself. To make the class become the students' center, the teacher used the discussion and role-play strategy.

\section{d. The Developing of The Students' Interest To Read And Write}

The data shows that the teacher has been developed the students' interest to read and write in her English lesson plan. In the lesson plan, this characteristic can be seen also in the whilst activity. The researchers used to cite the part of collecting information from the lesson plan made by the teacher for the second meeting. The teacher wrote in her lesson plan to ask the students to write their daily activities and compare to the daily activities shown in the story. This activity try to give the opportunity to the students to write. In this case, the teacher ask the students to write their daily activities.

\section{e. Giving Feedback To The Students}

The finding of this part is the teacher give her student feedback on the lesson plan. The teacher wrote in the part of collecting feedback on her lesson plan to give the opportunities to the other students to give feedback to their friend's result with the evaluation and the adding information, tells the students' mistakes in asking and giving information related to the situation or event that is being done or ongoing activity, and ask the students to answer the questions given by the teacher based on the pictures displayed on the powerpoint slade show. Based on this finding on the lesson plan made by the teacher, the researchers conclude that the teacher put the feedback on her lesson plan such as give the opportunities to the other students to give feedback to their friends and tells the students' mistakes.

f. The Interrelationship between the Basic Competencies, Learning Material, Learning Activities, Indicators of Competency Achievement, Assessment, and Sources

The researchers found that all the lesson plan has the interrelationship in all the variables. For example in the second meeting, the teacher put the KI 3 as the core competencies. Then, the teacher used KD 3.8 for the basic competencies and 3.8.1 also 3.8.2 as the indicators of competency achievement. The teacher used the assessment related to asking and giving information as a part of the competencies and the teacher used some references to support the teaching materials such as the hand book for the 
seventh grade and the internet. To emphasize the interrelationship between basic competencies, learning material, learning activities, indicators of competency achievement, assessment, and sources the teacher said that the teacher used some references in creating the lesson plan, then she combine the learning methods. The using of learning methods depends on the school facility also the needs of the learning methods in the teaching and learning process.

\section{g. Integrated Thematical Learning}

Based on the lesson plan collected by the teacher, the researchers found that the teacher used two themes for five meetings. To find the deeper information about the thematical learning in the lesson plan, the teacher did the interview with the teacher. At this moment, the teacher said:

"Yes, each chapter has its own theme. For example in the class VII, the general theme is about 'what are you doing.' Then each chapter divide into some meetings, for example for three meetings. At the first meeting, I will explain about 'what are you doing' and the sentence use for it. At the second meeting, I will explain about yes no question and the WH questions for the third meeting."

The teacher's statement confirm that the teacher integrated thematical learning because she use a different theme for every meetings.

\section{h. The Application of Technology In The Process of Teaching and Learning}

The teacher wrote in her lesson plan that the media are book, white board, board marker, pictures, also picture and flash card. It means that the teacher applied the ICT in her lesson plan. The teacher explain why she only used picture as media for teaching English in the classroom. The reason is that there is no electric in this school. This is one of the limitations in the school in rural area.

Based on the analysis on the parts of learning objectives, the researchers conclude that the teacher bring Higher Order Thinking Skills (HOTS) in her lesson plan. This finding appropriate to the theory about the content of HOTS lesson plan for 2013 Curriculum, where the lesson plan should give attention to the students' characteristics, students' participation, student center, develop students' interest to read and write, giving feedback to the students, emphasize the relationship of basic competencies, learning material, learning activities, indicator of competency achievement, assessment, and sources, integrated thematical learning, and the application of the technology in the process of teaching and learning. Beside that, this finding suitable with the theory about 
determining learning objectives develop by Limbach and Waugh ${ }^{19}$ stated that the good lesson plan for HOTS must be consider with learning objectives as well as the activities and assessments, require students a specific behavior, introduce and practice the desired behavior and end with the learner exhibition of the behavioral response.

\section{Teaching HOTS In The Stage of Teach Through Questioning}

When the researchers observe the teaching and learning process, the researchers found that the teacher develop students' Higher Order Thinking Skills by teach through questioning. For example, in the fourth meeting the teacher read the dialogue on the textbook, then she ask the students about the information from that dialogue. Based on the observation that the researchers did in the teaching and learning process, the teacher did not apply teach through questioning in every meeting of English class. In the first meeting the teacher reads the text and explains the students' to find the regular activity from the text. It means that the teacher give her students all the information about teaching materials. This activity supported by the teacher's statement in the interview, she said:

"I often to ask the students about the meaning or something like that. For example, she know the meaning of the word, but she is not understand about it.... Ya, just asking the meaning (of the word). (the students) then already knows the meaning. For example in a sentence, she asked this meaning, playing this, this ball, just connecting to the sentences like that, or she ask, for example, it means this or something like that, just interpreting the whole that she does not know."

From this statement, it can be interpret that the teacher teach the students by questioning. This statement also supprot by the students where the student said:

"Asking about what should we do.... giving the meaning (of word) that the teacher said."

The question used by the teacher related to low order thinking skills (LOTS) because the teacher just ask the students about the meaning of the words. This type of question belongs to the verb translating. Based on the verbs used in assessment for the level of thinking develop by Eber and Parker (2009), this verb belongs to understanding as a part of low order thinking skills.

The questioning technique can help the students to explore their thinking ability. To develop the students' Higher Order Thinking Skills, the teacher needs to give the

\footnotetext{
${ }^{19}$ Barbara Limbach \& Wendy Waugh, "Developing Higher..., 1- 9
} 
high level questions to the students to make the students familiar with the concept of HOTS. Based on this theory and the finding of this research, the researchers found that the activity of teach through questioning did not match with the theory of teach through questioning for HOTS. Since the teacher give LOTS questions for the students, it can bring the students to the low order thinking skills because the level of students' thinking influenced by the type of questions given by the teacher.

\section{Teaching HOTS in the Stage of Practice Before Assessment}

The finding indicates the teacher did practice before assessment in English class. When the researchers did the observation, the researchers found that the teacher ask the students to discuss in every meetings. Teacher starts the class by divided the students into some groups and give the learning materials to them to discuss with their group. The teacher usually use group discussion also plays a game with the students to make the student to practice. She said that this strategy can help the student to be more comfortable to practice.

Practice before the assessment aims to give the students opportunity to explore their knowledge and make the students understand about the materials, skills, attitudes, and behavior that was be evaluate. This step was applied by the teacher where the teacher gives a time to the students to practice about how to make a dialog to their friends. The response of the students in this part is good where they can use the opportunity to practice even not all of them participate the practice to make a dialog in English. As long as the researchers observe the teaching and learning process, the teacher used the group discussion for every meetings. The problem is, not all students active to the process of practice in English class. Some students just keep silent in the process of discussion. The meaning of practice for HOT might be participating in higher level thinking like pose arguments, state opinions, look for evidence, critique the evidence, and think with fair-mindness. In this case, the using of group discussion might pose the students high thinking skills if all students can participate in the activity. So, the researcher conclude that the teacher do the practice before assessment but this strategy is not effective because most of the students are not active in their group.

\section{Teaching HOTS in The Stage of Review, Refine and Improve}

From the interview with the teacher, the researchers noted that the teacher do not collect the students' feedback because none of students give her feedback while 
teaching and learning process. As she said, "We explain why they got C. However, there are no students complained to me, they just accepted every statements." This statement also supports by the observation that the researchers did in the teaching and learning process. At the third meeting, the teacher made some error in her sentences. She said, "Any your friend not come today?" this sentence will be better if the teacher said, "Anybody absent today?" and then she also said, "who is?" this sentence is not a complete sentence and the context of the sentence itself. Actually, there are three students was absent that day. So, it will be better if the teacher say "Who are they?" Even the teacher made those errors, the students did not give any feedback to the teacher or correct the teacher that her sentence was error.

In the process of teaching English, the researchers did not find that the teacher do the step of review, refine, and improve. So that, the researchers did the interview with the teacher to find the deeper information about it. To find the teaching materials, the teacher said:

"I took from the textbook and other sources... internet... Just like the teaching materials. There are the text like yesterday. I took the text that I used yesterday from the internet."

The researchers found that the teacher believe that she has been reviewed the materials from some sources to use in English class. The teacher refines the materials that she got from some sources and combine the materials with the students' environment. But the meaning of review in this part is about reviewing the process of teaching and learning by collecting feedback from the students. In the observation process, the researchers did not find that the students' give the feedback to the teacher. Then when the researchers ask the teacher about the students' feedback, she said that she never get it from the students because all of them always agree to the teacher's statements.

The process of review, refine, and improve is the teacher activity to develop the quality of English teaching process. Since the teacher did not collect the feedback from the students, this finding not suitable to the theory of Limbach and about the review, refine, and improve. Limbach \& $\mathrm{Waugh}^{20}$ stated that the teacher can refine and improve

\footnotetext{
${ }^{20}$ Barbara Limbach \& Wendy Waugh, "Developing Higher ..., 1 - 9
} 
the materials by the students' feedback. Collecting feedback from the students is a method to find the students' need in the teaching and learning process.

\section{Teaching HOTS In The Stage of Provide Assessment and Feedback}

The feedback that the teacher give in this meeting was confirming the students' answer in front of the class. To create the assessments, the teacher combined materials from some sources and it would be based on the stadard competencies. The teacher also stated that some students cannot reach the standard of assessment because they are do not understand about what to do. The teacher in her statement explained:

"I took the assessment from the internet, sometimes I create by myself. Present continuous, for example, just make the sentences. Then find the supporting picture from the internet."

This statement tells us that the teacher combine the assessment from the internet and also used to create her own assessments. When the teacher looking for some references to create the statements, it means that the teacher use the valid assessment for the students. Then, the teacher also create her own assessments it means that the teacher can assess her students by her own standard.

Assessment is a process to evaluate the students' performance in learning process. In this step, the teacher assess the students and then give relevant feedback to them based on their performance. ${ }^{21}$ To assess the students, the teacher do the multiple choice questions, but she did not give the feedback to the multiple choice questions. On the other hands, the teacher give the feedback directly after the students present the result of their discussion in front of the class.

\section{Conclusion}

Based on the finding and the discussion, it can be conclude that the rural teacher did some steps to teach the rural junior high school students' Higher Order Thinking Skills. The steps are (1) The teacher determining learning objectives with the characteristics of the 2013 curriculum such as analyzing the students' characteristics, students participation, student center, developing students' interest to read and write, giving feedback to the students, interrelationship between basic competencies, learning material, learning activities, indicator of competency achievement, assessment and

\footnotetext{
${ }^{21}$ Merta Dhewa Kusuma, Undang Rosidin, Abdurrahman, and Agus Suyatna, "The Development of Higher..., 26-32
} 
sources, integrated thematical learning, and the application of technology in the teaching and learning process; (2) Teach through questioning with low order thinking questions; (3) Giving practice to the students by using group discussion, but this strategy is not effective to use for the rural students; (4) The teacher miss the part of review, refine, and improve because she did not collect the students feedback as a key of this part; (5) Provide assessment and give feedback to the students after the assessment.

Based on the finding of this research, the researchers suggest the teachers to follow the steps in teaching Higher Order Thinking Skills. The researchers also suggest the teacher to develop their teaching strategy to motivate the students to learn English and explore their thinking skills. The researchers hope that this research can be use as a reference about the process of implementing the curriculum to the curriculum developer and also the government as a head of education in Indonesia.

\section{E. References}

Baki, Nurshila Umar, Shammemm Rafik-Galea, and Vahid Nimehchisalem. "Malaysian Rural ESL Students Critical Thinking Literacy Level: A Case Study." International Journal of Education and Literacy Studies, Vol. 04, No. 04 (2016): 71-80.

Forehand, Mary. "Bloom's Taxonomy, Emerging Perspectives on Learning, Teaching and Technology." 2011. http://projects.coe.edu/epltt/index.php

Hart, L. Gary, Eric H. Larson, and Denise M. Lishner. "Rural Definition for Health Policy and Research." American Journal of Public Health, Vol. 95, No. 7 (2005): 1149-1155.

Helmawati. Pembelajaran and Penilaian Berbasis HOTS, Higher Order Thinking Skills. Bandung: PT Remaja Rosdakarya, 2019.

Krathwohl, David R. "A Revision of Bloom's Taxonomy, An Overview." Theory into Practice, Vol. 41, No. 4 (2002): 212-264.

Kusuma, Merta Dhewa, Undang Rosidin, Abdurrahman, and Agus Suyatna. "The Development of Higher Order Thinking Skills (HOTS) Instrument Assessment in Physics Study." Journal of Research and Method in Education, Vol. 7, No. 1 (2017): 26-32.

Lee, Sangmin-Michael. "The Relationship Between Higher Order Thinking Skills, Cognitive Density, and Social Presence In Online Learning." Internet and Higher Education, 21 (2014): 41-52.

Limbach, Barbara \& Wendy Waugh. "Developing Higher Order Thinking." Journal of Instructional Pedagogies, Vol. 3 (2010): 1-9. 
Prasad Mainali, Bhawani. "Higher Order Thinking in Education." Academic Voices, Vol. 2, No. 1 (2012): 5-10.

Raiyn, Jamal. "The Role of Visual Learning in Improving Students' Higher-Order Thinking Skills." Journal of Education and Practice, Vol. 07, No. 24 (2016): 115-121.

Retnawati, Heri. Hasan Djiu, Kartianom, Ezi Apino, and Rizqa D. Anazifa, "Teachers' Knowledge About Higher-Order Thinking Skills and Its Learning Strategy." Problem of Education in the $21^{\text {st }}$ Century, Vol. 76, No. 2 (2018): 215-230.

Row, Bavani Nageswana, Selvaranee Subramaniam, Renuka V. Sathasivam. "When Students Say 'I Just Couldn't Think': Challenges in Teaching Skilful Thinking.” The Malaysian Online Journal of Educational Sciences, Vol. 4, No. 2 (2016): 59-69.

Schouten, Marleen, C. Martijn van der Heide, Wim J.M. Heijman." Resilience of Social-Ecological Systems in European Rural Areas: Theory and Prospects." Research Gate, January 2009, Available at https://www.researchgate.net/publication/46472588 